\title{
Trainee-in-parenting in the time of COVID-19
}

\section{Sarah Palmer, MD}

$\mathrm{M}$ y role as a mother expands and contracts in hard-won harmony with my role as a psychiatry resident. The magnitude of this responsibility compounded on itself when, seemingly overnight, the world we once trusted suddenly became unsafe. Coronavirus disease 2019 (COVID-19), deadly to immunocompromised individuals and the harbinger of a lethal autoimmune syndrome in children, was at our doorstep.

\section{COVID-19 and parents who work in health care}

After COVID-19 reached the United States, my fellow residents and I began to exchange nervous text messages, wondering what we could expect. Not only did the biological threat of the virus loom at the limited hospital entry points, but news alerts about infected front-line health care professionals and supply shortages jammed our cellphones. We quickly learned that some front-line physicians and nurses in New York had decided to live separately from their families. One article reported that a resident who was 5 months postpartum had chosen to live separately from her infant to protect her from exposure. "What a fundamental conflict of identity," I thought as I read the article. Looking at my own young family, I felt our vulnerability overcome me. Would I have to do the same?

Difficult choices that exemplify both excitement and fear seem to define parenthood. Only months ago, I was selecting a

car seat. As I scoured consumer reports, I became aware of a harrowing irony: in the excitement of nesting, I was also preparing for a collision. In March, when the quarantine began, I found myself evaluating my options for how to protect my family during a pandemic that often feels like a car crash in slow motion.

Health care professionals began to separate from their families to reduce the risk of transmission. Whether children went to live with relatives or health care workers stopped snuggling their young children, a structural boundary was formed just as the roots of attachment were taking shape. When asked about the loss inherent in this separation, these young parents expressed sadness but also said the choice was clear: their need to protect their families was absolute.

Meanwhile, some residents found themselves in a crash course on telemedicine. Safe from coronavirus exposure at work and liberated from a daily commute, these parents saw their young children more than ever before. Young children saw their parents who were residents more than ever before. Perhaps the isolation of a front-line resident was sadly not a new experience.

continued

LET YOUR VOICE BE HEARD

CURRENT PSYCHIATRY invites psychiatry residents to share their views on professional or clinical topics for publication in Residents' Voices. E-mail jbauer@mdedge.com for author guidelines.

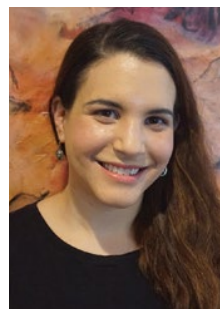

Dr. Palmer is a PGY-3 Psychiatry Resident, Integrated Adult/ Child Psychiatry, University of Massachusetts Medical School, Worcester, Massachusetts.

Disclosure

The author reports no financial relationships with any companies whose products are mentioned in this article, or with manufacturers of competing products.

doi: 10.12788/cp.0048 
Clinical Point

While COVID-19 hit us hard, it has also forced a rare opportunity for self-assessment of priorities that we as trainees rarely take

\section{Reassessing priorities}

Now that the first wave of infections has broken over our coastal cities, residents from the front lines of COVID-19 are reuniting with their families. The sacrifices they made are re-evaluated as they begin to recognize anew the value of physical closeness with their loved ones in a dangerous world. One family that separated during the first wave said they would plan an alternate strategy, perhaps invest in a babysitter, rather than divide the household a second time.
While COVID-19 hit us hard, it has also forced a rare opportunity for self-assessment of priorities that we as trainees rarely take. We don't have a consumer report on the safety ratings of COVID-19 plans. There is no formula for success. Instead, we each balance work and personal life with individual strategies to cope with elements outside of our control. This coping strategy may look different for each family. I hope all training departments take this plurality into account when considering the new demands on residents that have emerged during COVID-19. 